against more resistant organisms outside hospital has been growing, since antibiotic resistance is no longer the hallmark of hospital bacteria. Inevitably over the years some patients who acquired such strains have exported them into the community either overtly-for example, in their surgical wounds or urine-or covertly, among their faecal flora. The opportunities for the spread of such organisms in the wider community are much less than they are in hospital, but they have made appreciable advances. For example, beta-lactamaseproducing staphylococci now heavily predominate among softtissue infections in outpatients, ${ }^{16}$ and resistance to beta-lactam antibiotics has become definitely more common among urinary pathogens. ${ }^{17}$ It is a matter of nice judgment at what point the prevalence of resistance has become sufficiently high to justify treatment with an agent active against both the resistant minority and the sensitive majority of infecting organisms, but the activity of amoxycillin-clavulanic acid by mouth certainly brings the treatment of infections due to betalactamase-producing organisms much more readily within the reach of general practice.

Disturbance of the gut flora does not appear to have been a problem in treated patients; whether the repair to amoxycillin's beta-lactamase lability is sufficiently secure to control the emergence and overgrowth of resistant strains if the agent comes to be widely used, only time will tell.

F W O'GRADY

Professor of Microbiology,

University Hospital,

Queen's Medical Centre

Nottingham NG7 2UH

${ }^{1}$ Batchelor FR, Doyle FP, Nayler JHC, Rolinson GN. Synthesis of penicillin : 6-aminopenicillanic acid in penicillin fermentations. Nature 1959; $183: 257-8$.
${ }^{2}$ Rolinson GN, Stevens S, Batchelor FR, Wood JC, Chain EB. Bacteriological studies on a new penicillin-BRL 1241. Lancet 1960;ii:564-7.

${ }^{3}$ Greenwood D, O'Grady F. Potent combinations of $\beta$-lactam antibiotics using the $\beta$-lactamase inhibition principle. Chemotherapy $1975 ; 21: 330-41$.

4abath LD, Elder HA, McCall CE, Finland M. Synergistic combinations of penicillins in the treatment of bacteriuria. N Engl f Med 1967;227: 232-8.

${ }^{5}$ Reading C, Cole M. Clavulanic acid: a beta-lactamase-inhibiting betalactam from Streptomyces clavuligerus. Antimicrob Agents Chemother $1977 ; 11: 852-7$.

${ }^{6}$ Wise $\mathrm{R}$, Andrews JM, Bedford KA. In vitro study of clavulanic acid in combination with penicillin, amoxycillin and carbenicillin. Antimicrob Agents Chemother 1978;13:389-93.

${ }^{7}$ Jackson RT, Harris LF, Alford RH. Sodium clavulanate potentiation of cephalosporin activity against clinical isolates of cephalothin-resistant Klebsiella pneumoniae. Antimicrob Agents Chemother 1978;14:118-25.

${ }^{8}$ Wise R, Andrews JM, Bedford KA. Clavulanic acid and CP-45, 899: a comparison of their in vitro activity in combination with penicillins. $\mathcal{f}$ Antimicrob Chemother 1980;6:197-206.

- Wise R, Gillett AP, Andrews JM. The in vitro activity of mezlocillin when combined with cefoxitin or clavulanic acid. $\mathcal{f}$ Antimicrob Chemother $1979 ; 5: 301-6$.

10 Hunter PA, Coleman K, Fisher J, Taylor D. In vitro synergistic properties of clavulanic acid, with ampicillin, amoxycillin and ticarcillin. $\mathcal{F}$ Antimicrob Chemother 1980;6:455-70.

1 English AR, Retsema JA, Girard AE, Lynch JE, Barth WE. CP-45, 899 a beta-lactamase inhibitor that extends the antibacterial spectrum of beta-lactams: initial bacteriological characterisation. Antimicrob Agents Chemother 1978;14:414-9.

12 Wise R, Andrews JM, Patel N. 6- $\beta$-bromo- and 6- $\beta$-iodopenicillanic acid, two novel $\beta$-lactamase inhibitors. 7 Antimicrob Chemother 1981 ; 7:531-6.

13 O'Callaghan CH. Description and classification of the newer cephalosporins and their relationship with the established compounds. $\mathcal{f}$ Antimicrob Chemother 1979;5:635-71.

14 Brogden RN, Carmine A, Heel RC, et al. Amoxycillin/clavulanic acid: review of its antibacterial activity, pharmacokinetics and therapeutic use. Drugs $1981 ; 22: 337-62$.

15 Rolinson GN, Watson A, eds. Proceedings of the 1st symposium on Augmentinclavulanate-potentiated amoxycillin. Amsterdam: Excerpta Medica, 1980

16 Hassam ZA, Shaw EJ, Shooter RA, Caro DB. Changes in antibiotic sensitivity in strains of Staphylococcus aureus 1952-78. Br Med f 1978; ii:536-7.

17 Grüneberg RN. Antibiotic sensitivities of urinarv pathogens 1971-8. f Clin Pathol 1980;33:853-6.

\title{
The achievement of Michael O'Donnell
}

One of the more attractive features of English life is the tradition of radical journalism. Examples such as Swift, Cobbett, Wilkes, William Morris, GBS, and George Orwell instantly spring to mind and, however disparate the aims, all their writings have some characteristics in common: zest, wit, readability, and purpose-which has often been achieved. Nevertheless, we have had few radical journalists in medicine. An obvious example is Thomas Wakley, founder of the Lancet, whose braggadocio still gives a lot of pleasure more than 150 years later. The claims could also be urged of the lesser-known but equally influential Ernest Hart, who, editing the $B M Y$ from 1867 to 1898 , was responsible for considering no fewer than 33 Parliamentary Bills in ten years, covering topics from baby farming (disguised infanticide) to the abolition of air pollution and the compulsory examination of the eyesight of railwaymen.

Since Hart's death, however, it would be difficult to think of any doctor who has ranged so widely in so public a fashion. Possibly this dearth of candidates is due to the restricted audience a medical journalist is likely to have; possibly because today change in medical organisation tends to be achieved slowly rather than rapidly, and by private rather than public negotiation; possibly, again, because such change is often likely to be thrust on to the profession by outside polemicists rather than to spring from within it.
All of this could have been said until fifteen years ago. For it was then that another radical medical journalist burst on the scene with the same panache as his predecessors. Michael O'Donnell, whose appointment as editor of World Medicine was abruptly ended two weeks ago, has put both the profession and the public in his debt. He has campaigned vigorously and successfully for the apparently impossible, such as reform of the GMC; he has got doctors to laugh at themselves and their practices; he has highlighted the pettiness of the jacks-inoffice and their new bureaucracy; and he has exposed awkwardness that the Establishment would sooner have forgotten about.

But Michael O'Donnell's achievement has been even greater than that: by giving a large number of doctors, paramedical workers, and laymen the opportunity to express all sorts of views in clear and crisp prose he has filled a gap between the staid scientific journals on the one hand and the medical newspapers on the other. The result has been a unique mixture of the rumbustious and the civilised, of the sublime and the awful (according to your taste), often written by those who have had to be coaxed into proving that they also could write well. Not to have read Michael O'Donnell's World Medicine was to have been incomplete as a doctor.

STEPHEN LOCK 